\title{
The behavior of apricot kernel oil body and proteins during in vitro gastric and intestinal digestion
}

\author{
Aslı Kancabas Kilinc, Sibel Karakaya* \\ Food Engineering Department, Faculty of Engineering, Ege University, Izmir, Turkey
}

*Corresponding Author: Sibel Karakaya, Food Engineering Department, Faculty of Engineering, Ege University, Izmir, Turkey. Email: sibel.karakaya@ege.edu.tr

Received: 7 October 2021; Accepted: 13 December 2021; Published: 25 January 2022

(c) 2022 Codon Publications

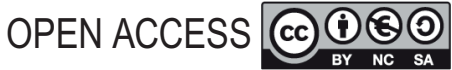

PAPER

\begin{abstract}
In this study, an apricot kernel milk suspension was prepared, for which Hacıhaliloğlu-type raw and roasted apricot kernels were used. Protein, total lipid, and ash contents of apricot kernels and apricot kernel milk were determined. Palmitic acid, oleic acid, and linoleic acid were considered as major fatty acids according to gas chromatography. During in vitro gastrointestinal digestion, the proteins of raw and roasted apricot kernel milk were hydrolyzed and pepsin-resistant proteins were determined. No difference was recorded between the pancreatic lipase penetration in the oil-water interface of oil bodies of both milk types.
\end{abstract}

Keywords: fatty acids; oil body; protein hydrolysis; vegetable milk; vegetable protein; waste by-products

\section{Introduction}

Currently, owing to the increasing global population and rising environmental concerns, demand for the sustainability of food and agriculture systems has been intensifying. The global consumption of meat and dairy products is projected to increase by $\sim 173 \%$ and $158 \%$, respectively, from 2010 to 2050 (Food and Agriculture Organization of the United Nations [FAO], 2011). In particular, considerable concerns for the production and consumption of animal protein in terms of environmental effects, such as increasing greenhouse emissions and water consumption, have caused increased interest in producing alternate sources of proteins, such as vegetable proteins, which are already present in the human diet (Fasolin et al., 2019). Moreover, the current intention of consumers to include additional plant-based proteins in their daily diet requires greater knowledge about using alternative protein sources and their impact on the human health. The by-products of alternative protein sources and food wastes have considerable potential to be included in the human diet, especially those rich in protein, vitamins, minerals, fibers, oils, and bioactive compounds (Coman et al., 2019; Morais et al., 2015).

Apricot (Prunus armeniaca L.) kernels, a valuable by-product obtained from the processing of apricot plants, can have the potential to be used as a functional food ingredient to increase product differentiation and accomplishment of consumer requirements. The total production of apricots in the world is 4.3 million tons per year, and Turkey itself produces $\sim 985,000$ tons (Turkey Ministry of Agricultural and Forestry, 2020). Turkey produces $10-12 \%$ of fresh apricot and $60-65 \%$ of dried apricot in the world; moreover, $\sim 10-20 \%$ of fresh apricot and $80-85 \%$ of dried apricot are exported throughout the world (Siğırcı et al., 2015). Moreover, the apricot kernel is rich in phytochemicals, vitamins, minerals, unsaturated fatty acids (oleic acid and linoleic acid), $\alpha$-, $\gamma$-, $\delta$-tocopherols, and fibers (Al Juhaimi et al., 2018; Fratianni et al., 2018). Lipids found in apricot kernel are in the form of oil body, in which triglyceride particles are 
coated with a stabilizing layer of phospholipids and proteins (Gallier et al., 2017). The oil body is a lipid-storage compartment in plant seeds and its structure is similar to that of emulsions. In most oil seeds, oil bodies have a diameter of $0.6-2 \mu \mathrm{m}$, while it could be $10-20 \mu \mathrm{m}$ in some fruits (Dave et al., 2019). Owing to easy extraction, high recovery yield, and safe use in food products, plantderived oil bodies have received considerable attention (Abdullah and Zhang, 2020). Several studies related to oil bodies from different sources have focused on their physicochemical characteristics such as droplet size, zeta $(\zeta)$ potential, emulsifying properties, and their microstructures (Dave et al., 2019; Ishii et al., 2017; Yan et al., 2016). However, few studies have investigated the behavior of oil bodies from different sources, including almond oil bodies, bovine milk fat globules, and sunflower oilseed bodies during in vitro digestion (Gallier et al., 2012, 2013; Mandalari et al., 2008; Wang et al., 2020; White et al., 2008). Certain studies have focused on the occurrence, structure, and allergenicity of oil bodies (Barre et al., 2018), the possibility of oil bodies derived from a plant source with unique facilities that could be used as an alternative to milk fat globules (Mantzouridou et al., 2019), the extraction, isolation, and characterization of oil bodies (Zderic et al., 2016), and the effects of food processing, such as roasting, sterilization, and highpressure homogenization, on oil bodies (Yan et al., 2016; Zaaboul et al., 2019).

Protein contents determined in various types of apricot kernels are reported as 15.1-24.2\% (Gezer et al., 2011). Moreover, proteins determined in apricot kernels contain high levels of tyrosine, cysteine, methionine, aspartic acid, glutamic acid, serine, proline, and alanine (Elkot et al., 2017). Owing to this valuable composition, especially protein and fat contents, the apricot kernel could be considered as a functional food or functional food ingredient. However, for the food industry, only a small amount of apricot kernel is consumed as nuts and a large amount is a waste by-product. Therefore, in spite of having a considerable industrial potential, lack of systematic collection and utilization has led to the lack of exploitation of this valuable product. The primary concern is amygdalin, a cyanogenic glycoside, contained in the kernels and seeds of apples, apricots, almonds, cherries, plums, and peaches (Mirzaei and Razei, 2019). Karsavuran et al. (2015) reported that the amount of amygdalin in sweet Hacihaliloğlu-type apricot seeds was $0.25 \mathrm{mg} / \mathrm{g}$ and the predicted amount of hydrogen cyanide was $0.014 \mathrm{mg} / \mathrm{g}$. With this amygdalin level, approximately $800-\mathrm{g}$ seed would have to be ingested to cause poisoning of a child weighing $20 \mathrm{~kg}$. However, this amount that causes poisoning in a child weighing $20 \mathrm{~kg}$ was very low for bitter apricot seeds (i.e., for Paviot-type, 4.48-g seeds; for Alyanak-type, 6.29-g seeds; and for Ninfa-type apricot, 12.87 -g seeds).
In recent years, rather than dairy products, plant-based food alternatives, such as vegetable milk extracted from soy, almond, rice, and oats, have increased. The beverage obtained from apricot kernel could be a good alternative. Generally, studies related to apricot kernel as a functional food ingredient were based on foods added with apricot kernel. Elkot et al. (2017) produced stirred yogurt supplemented with apricot kernel powder and reported an increase in the protein content of yogurt. Eyidemir and Hayta (2009) incorporated apricot kernel flour into the noodle and indicated the increased contents of protein, lipid, and ash in the noodle.

To our knowledge, the possibility of extracting vegetable milk from apricot kernel has not been studied to date. In addition, the physicochemical characteristics of oil bodies and proteins of apricot kernel and their behavior during in vitro gastrointestinal digestion have not been explored. As most apricot kernels are waste by-products, converting them into value-added products would be beneficial in terms of both waste utilization and human health. Therefore, in order to explore certain physicochemical properties of oil bodies and proteins, protein profile and protein hydrolysis during in vitro gastrointestinal digestion are substantial.

The objectives of this study are to: characterize certain physicochemical properties of oil bodies and proteins of apricot kernel milk, understand their behavior during in vitro gastrointestinal digestion, evaluate the effect of microstructure on the physicochemical properties of oil bodies, evaluate it as an alternative vegetable protein source, and, finally, investigate the effect of roasting on all these properties.

\section{Materials and Methods}

\section{Samples and reagents}

Apricot kernels (Hacıhaliloğlu-type) were supplied by Apricot Research and Application Centre, Inonu University, Malatya, Turkey.

Following chemicals were purchased from Sigma Aldrich Corporation (St. Louis, MO, USA): Bradford reactive (B6916), bile acid (B8631), pepsin (P7000), pancreatin (P7545), glycine (G8898), bromphenol blue (B0126), Coomassie brilliant blue R (27816), sodium dodecyl sulfate (L4390), marker for sodium dodecyl sulfatepolyacrylamide gel electrophoresis (SDS-PAGE; S8445), and fatty acids methyl esters standard (47885-U). MiniPROTEAN TGX precast gels (12\%) were purchased from Bio-Rad (New York, USA). All the chemicals were of analytical grade. 


\section{Preparation of apricot kernel milk}

For preparing apricot kernel milk, $250 \mathrm{~g}$ of apricot kernel was soaked overnight in 1-L ultrapure water at room temperature. The mixture was subjected to agitation with a blender, and filtered using a cheesecloth. The supernatants were stored at $-20^{\circ} \mathrm{C}$ until analyzed. The amount of kernel in the final product was $20 \mathrm{~g} / 100 \mathrm{~mL}$.

\section{Roasting}

Apricot kernels were roasted in an oven for $10 \mathrm{~min}$ at $170^{\circ} \mathrm{C}$, and the roasting process was selected as it was generally applied to nuts.

\section{Chemical composition}

The protein contents of apricot kernel and both kinds of milk were determined by Dumas method using LECO-FP 528 analyzer. The protein contents of digested samples were determined using the Bradford (1976) method, and bovine serum albumin (BSA) was used as a standard. The total lipid contents of apricot kernel and apricot kernel milk were detected using the methods proposed by Folch et al. (1957) and Bligh and Dyer (1959), respectively.

\section{In vitro gastrointestinal digestion}

The samples were subjected to in vitro gastrointestinal digestion (Minekus et al., 2014). Accordingly, simulated salivary fluid (SSF), simulated gastric fluid (SGF), and simulated intestinal fluid (SIF) were prepared daily from stock solutions. In this method, the activities of enzymes were determined as per the protocol described by Brodkorb et al. (2019). Pepsin and pancreatin were used in gastric digestion and intestinal digestion, respectively. Pefabloc was used to stop enzymatic activity.

\section{Protein profile}

The protein profiles of milk from roasted and unroasted apricot kernels and aliquots obtained from in vitro gastric and gastrointestinal digestions were determined using SDS-PAGE. Then the samples were diluted to a protein concentration of $1 \mathrm{mg} / \mathrm{mL}$ and mixed with sample buffer solution in a $1: 1$ ratio. The samples were maintained at $95^{\circ} \mathrm{C}$ for $10 \mathrm{~min}$ and then loaded on gels $\left(12 \%\right.$ Mini-PROTEAN $^{\circ}$ $\mathrm{TGX}^{\mathrm{TM}}$ precast gels) as $40 \mu \mathrm{L}$ for gastric samples and 20 $\mu \mathrm{L}$ for intestinal samples. Moreover, electrophoretic separations were conducted at $150 \mathrm{~V}$ using a running buffer, and gels were stained with Coomassie brilliant blue R-250 solution (50\% ethanol and $10 \%$ glacial acetic acid).

\section{Analysis of fatty acid}

The major fatty acids of apricot kernel were quantified using 7820A GC gas chromatography system (Agilent Technologies, Santa Clara, CA, USA) with a flame ionization detector (FID) and conventional injector. A fused silica capillary column was used (J\&W DB-23, 30-m $\times$ 0.25 -mm inner diameter, 0.25- $\mu \mathrm{m}$ film thickness; Agilent Technologies).

Methyl esters were prepared using the official method Ce 2-66 of American Oil Chemists' Society (AOCS). The procedure described by Wu et al. (2011) was applied with slight modifications, and the injection volume was $1 \mu \mathrm{L}$. The temperature in both injector and detector was $250^{\circ} \mathrm{C}$. The temperature program was started at $45^{\circ} \mathrm{C}$, held for 4 min, increased to $175^{\circ} \mathrm{C}$ at a rate of $15^{\circ} \mathrm{C} / \mathrm{min}$, held for $15 \mathrm{~min}$, then increased to $215^{\circ} \mathrm{C}$ at a rate of $4^{\circ} \mathrm{C} / 5 \mathrm{~min}$ and held for $10 \mathrm{~min}$. Supelco 37 component fatty acid methyl esters (FAME) mixture was used for identifying fatty acids.

\section{Total titratable acid release}

The rate of free fatty acid release was monitored using a pH-stat titration unit (Automatic Potentiometric Titrator AT-510; KEM, Kyoto, Japan). NaOH solution, $0.1 \mathrm{M}$, was used to maintain $\mathrm{pH}$ at 7.0 for $2 \mathrm{~h}$ at $37^{\circ} \mathrm{C}$. Samples obtained from gastric digestion were subjected to $\mathrm{pH}$-stat titration to determine release of free fatty acid. An excessive amount of pancreatic lipase was added to sample at the end of gastric phase to obtain the lipase activity of $2,000 \mathrm{U} / \mathrm{mL}$ as recommended by Mat et al. (2016).

\section{Measurement of zeta potential}

The zeta potentials of apricot kernel milk, roasted apricot kernel milk, and digested samples were measured using Malvern Zeta Sizer Nano ZS. The apricot kernel milk was diluted 100-fold with purified water, gastric digested samples were diluted with citrate buffer $(\mathrm{pH}=2.5)$, and intestinal digested samples were diluted to 100-fold with phosphate buffer ( $\mathrm{pH}=7.2$ ) according to the procedure proposed by Gallier and Singh (2012).

\section{Optical microscopy}

The images of the microstructures of oil bodies of milk and digested samples were taken with motorized light microscope PSARON Floptik (HPTS 150, AIV Labs, Ankara, Turkey) equipped with a controlled vehicular access (CVA) camera using a digital image. A drop of the 
sample was placed on a microscope slide, covered with a cover glass, and detected with a $10 \times$ objective lens.

\section{Statistical analysis}

Parallel proximate analysis was conducted in triplicate. Data were analyzed using ANOVA (SPSS for Windows version 18.0) and comparisons between mean values were performed using a $t$-test. Differences between mean values were considered significant at $p<0.05$.

\section{Results and Discussion}

\section{Chemical composition of apricot kernel and apricot kernel milk}

Table 1 lists protein, total lipid, and ash contents of apricot kernel and apricot kernel milk. Protein, total lipid, and ash contents of apricot kernel were higher than that of apricot kernel milk $(p<0.05)$. Different results were reported for protein $(15.1 \%-24.2 \%)$ and total lipid contents (27.7-66.7\%) (Alpaslan and Hayta, 2006; Gezer et al., 2011). Differences in the chemical compositions of apricot kernels were due to their physical characteristics such as kernel weight and length (Femenia et al., 1995).

\section{Proteins hydrolyze during in vitro gastrointestinal digestion}

There were 10 protein bands in the SDS-PAGE profile of samples; their molecular weight (MW) was between 97 $\mathrm{kDa}$ and $6.5 \mathrm{kDa}$ (Figure 1A). In the unroasted form, three protein bands whose molecular weight was 97,66 , and 66-55 kDa might correspond to storage proteins, specifically nutrient reservoir protein $(96 \mathrm{kDa})$, Prunin 1 (63 $\mathrm{kDa})$, and Prunin $2(53 \mathrm{kDa})$ as reported by Ghorab et al. (2018). Moreover, the authors indicated that the protein bands with molecular weight of 45, 36, and $29 \mathrm{kDa}$ could be hexosyltransferase $(43 \mathrm{kDa})$, hydroxyisourate hydrolyze activity $(37 \mathrm{kDa})$, and ribosomal protein S18 (31 $\mathrm{kDa}$ ), respectively. In the roasted form, the disappearance of two protein bands with molecular weight of 97 and
14.2 $\mathrm{kDa}$ might be attributed to the breakdown of these proteins during roasting. The SDS-PAGE patterns of in vitro gastric digestion of apricot kernel milk (Figure 1B) demonstrated that there were no differences in the protein bands of the samples obtained from gastric chyme at different time intervals. This result indicated that pepsin was not able to hydrolyze proteins with molecular weight of 97 and $66 \mathrm{kDa}$. Protein band with MW $=20 \mathrm{kDa}$ in the SDS-PAGE profile of gastric digested apricot kernel milk but not in the undigested apricot kernel milk might be a sign of the breakdown of proteins with $\mathrm{MW}>20 \mathrm{kDa}$. A similar SDS-PAGE profile was obtained for in vitro gastric digestion of roasted samples (Figure 1C).

Intestinal enzyme pancreatin contains proteases with a molecular weight of 23.8-64 kDa, amylase with a molecular weight of 51-55.4 kDa, lipase with a molecular weight of $45-50 \mathrm{kDa}$, chymotrypsin with a molecular weight of $25 \mathrm{kDa}$, trypsin with a molecular weight of $24 \mathrm{kDa}$, and ribonuclease with a molecular weight of 13.7-14.7 kDa. Protein bands with molecular weight of 45,24 , and $~ 13$ $\mathrm{kDa}$ were present in the enzymes of intestinal digestive system (Figures $1 \mathrm{D}$ and E). Four protein bands (with MW $=45,29,20$, and $6.5 \mathrm{kDa}$ ) were observed in apricot kernel milk whereas seven protein bands (with $M W=45$, $36-37,29,24, \sim 22,6.5$, and $<6.5 \mathrm{kDa}$ ) were observed in roasted apricot kernel milk during intestinal digestion (Figure 1E). The fact that protein bands with MW $>45$ $\mathrm{kDa}$ present in the SDS-PAGE profile of the gastric digestion system did not appear in the first $15 \mathrm{~min}$ of intestinal digestion indicated that these proteins were hydrolyzed in the first $15 \mathrm{~min}$ of intestinal digestion. As reported by Beisson et al. (2001), for almond oleosins, the $6.5-\mathrm{kDa}$ protein fraction that was not hydrolyzed during intestinal digestion as a function of time might be the central hydrophobic domain of apricot kernel oleosins. Proteins with $\mathrm{MW}>45 \mathrm{kDa}$ were completely hydrolyzed at the end of intestinal digestion.

The disappearance of bands with MW $>45 \mathrm{kDa}$ present in the SDS-PAGE profile of gastric digestion established the hydrolysis of proteins with a higher molecular weight during intestinal digestion. The observation of fractions with molecular weight of $45-6.5 \mathrm{kDa}$ could be attributed to the hydrolysis of proteins with a higher molecular weight.

Table 1. The proximate composition of apricot kernel and apricot kernel milk.

\begin{tabular}{lrrrr} 
& Apricot kernel & Roasted apricot kernel & Apricot kernel milk & Roasted apricot kernel milk \\
\hline Protein (\%) & $21.65 \pm 0.08^{\mathrm{a}}$ & $22.98 \pm 0.98^{\mathrm{a}}$ & $3.78 \pm 0.72^{\mathrm{b}}$ & $3.97 \pm 0.81^{\mathrm{b}}$ \\
Total lipid (\%) & $26.22 \pm 1.40^{\mathrm{c}}$ & $25.87 \pm 5.67^{\mathrm{c}}$ & $7.74 \pm 3.79^{\mathrm{d}}$ & $6.53 \pm 2.45^{\mathrm{d}}$ \\
Ash (\%) & $2.55 \pm 0.20^{\mathrm{e}}$ & $2.36 \pm 0.51^{\mathrm{e}}$ & $0.15 \pm 0.07^{\mathrm{f}}$ & $0.11 \pm 0.1^{\mathrm{f}}$ \\
\hline
\end{tabular}

Values are mean \pm standard deviation.

Different letters in the same row indicate statistical significance at $p<0.05$. 

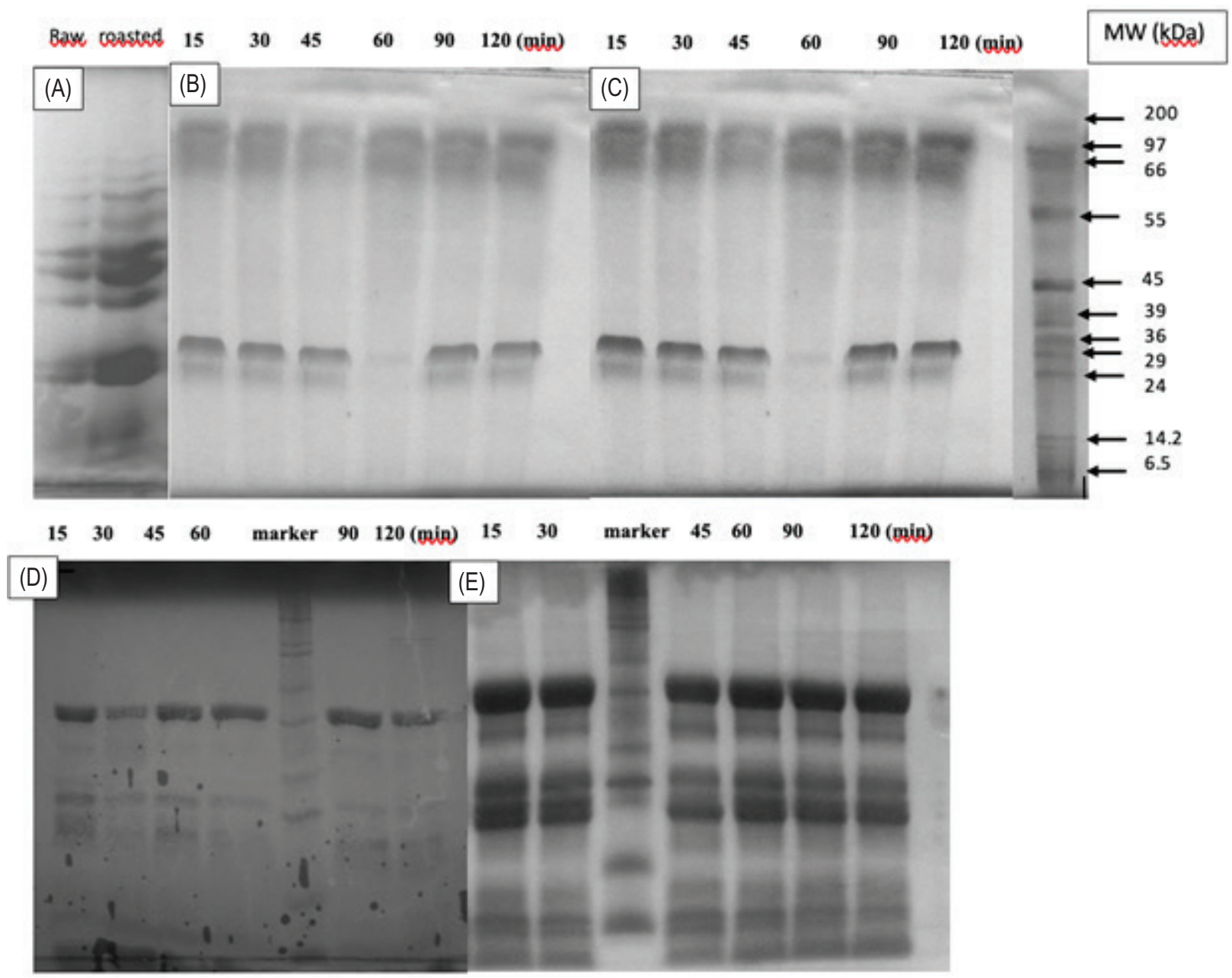

Figure 1. SDS-Page patterns. (A) Apricot kernel milk; (B) in vitro gastric digests of apricot kernel milk; (C) in vitro gastric digests of roasted apricot kernel milk; (D) in vitro intestinal digests of apricot kernel milk; and (E) in vitro intestinal digests of roasted apricot kernel milk.

In a study conducted by Gallier and Singh (2012), three primary almond protein bands (20-42 kDa) determined in tricine SDS-PAGE were hydrolyzed in the first $15 \mathrm{~min}$ of gastric digestion. The acidic polypeptides were hydrolyzed into smaller peptides in the first 2 min of intestinal digestion and the hydrolysis of all peptides was completed after 5 min of intestinal digestion. Different results obtained in these two studies could be related to $\mathrm{pH}=1.5$ of gastric chyme used in the study conducted by Gallier and Singh (2012) and difference between the sources of proteins (almond kernel versus apricot kernel) used in both studies.

\section{Composition of fatty acid}

The oil and milk extracted from apricot kernels were primarily composed of fatty acids such as palmitic acid, oleic acid, and linoleic acid (Figure 2). Fatty acid profiles of both kernels were identical (Figures 2A and B). Similarly, high amounts of oleic acid and linoleic acid and a low amount of palmitic acid were determined in the apricot kernel oil (Fratianni et al., 2018; Mattheus et al., 2016).

\section{Total titratable acid release}

No lag phase was observed during release of total titratable acid from in vitro gastric digested apricot kernel milk oil bodies (Figure 3). This indicated that pancreatic lipase easily penetrated the oil-water interface. An early and rapid release of fatty acids from oil bodies was identified in the first $10 \mathrm{~min}$ of lipolysis. After $10 \mathrm{~min}$, there was a reduction in the lipolysis rate, although acid release continued slowly to reach a value of $76.5 \mu \mathrm{M}$ for apricot kernel milk and $85.5 \mu \mathrm{M}$ for roasted apricot kernel milk at the end of 2-h digestion. During the first $30 \mathrm{~min}$, the rate of free fatty acid release increased rapidly as the oil-water interface was easily accessible by pancreatic lipase. The rate of release of free fatty acid slowed down 
(A)

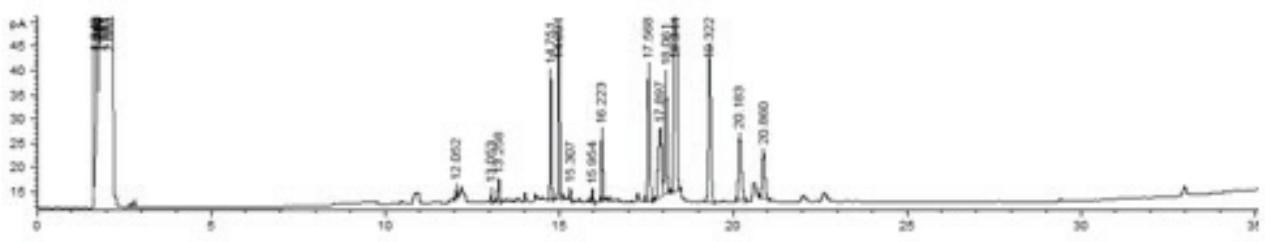

(B)

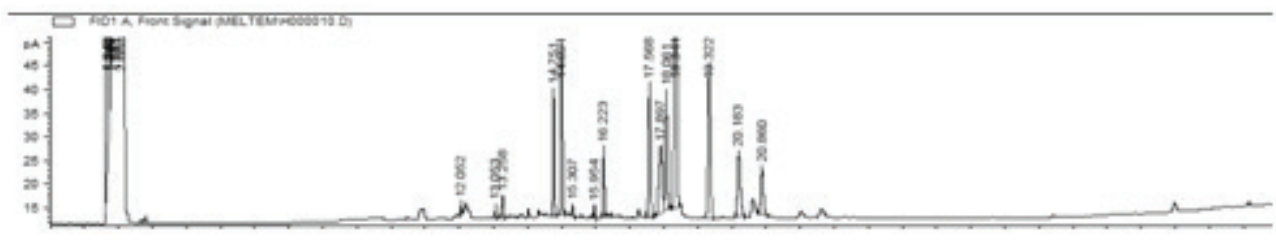

(C)

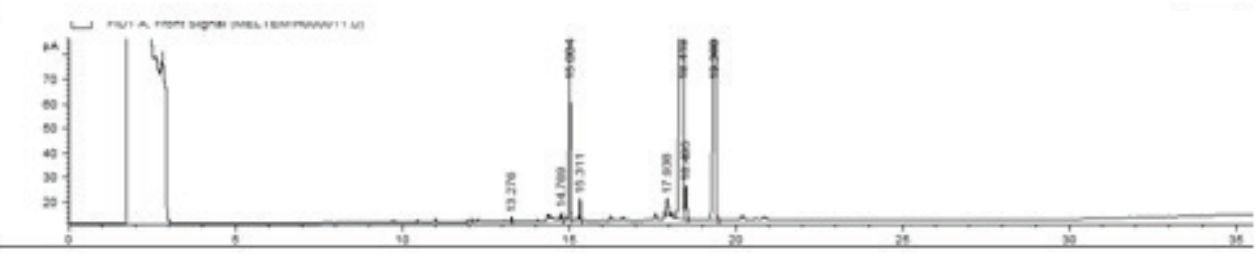

(D)

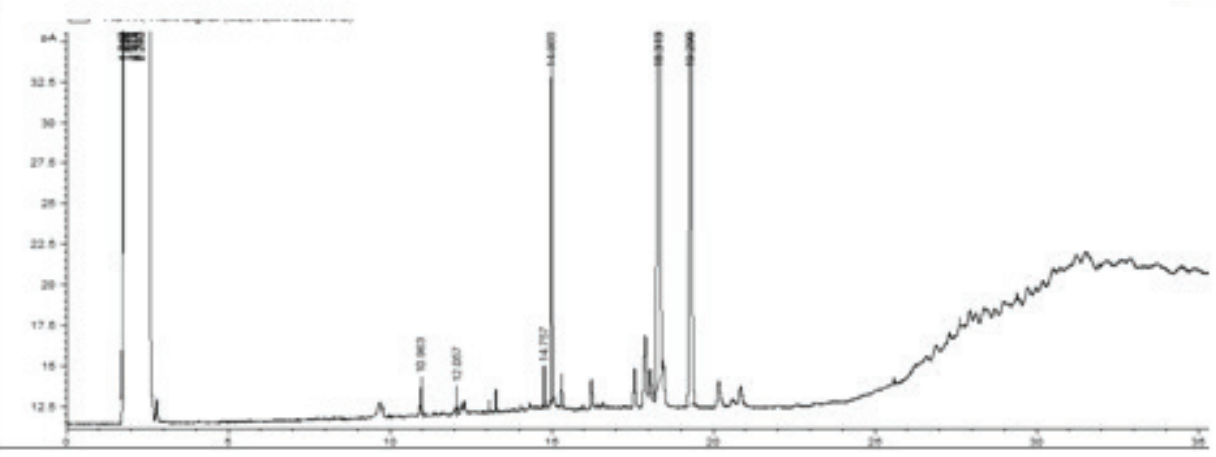

Figure 2. Gas chromatograms of apricot kernels. (A) Raw apricot kernel; (B) roasted apricot kernel; (C) apricot kernel milk; (D) roasted apricot kernel milk.

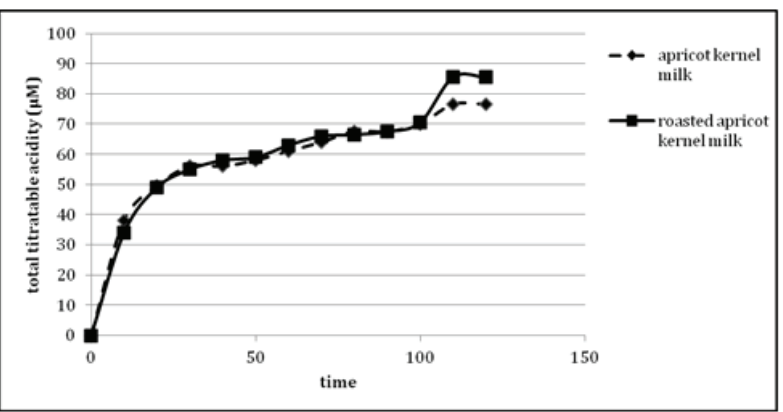

Figure 3. Total titratable acid release from gastric digested apricot kernel milk oil bodies during 120 min of intestinal digestion.

because the interfacial saturation of lipolytic products slowly solubilized into micelles. Unlike our result, Gallier and Singh (2012) observed a lag phase of $2 \mathrm{~min}$, indicating the prevention of lipolysis by the membranes of oil bodies of almond, and the release of $133-\mu \mathrm{mol} / \mathrm{mL}$ free fatty acids of almond oil bodies after in vitro intestinal digestion. Moreover, rapid increase in the release rate of fatty acid in the first $25 \mathrm{~min}$ of intestinal digestion was also identified.

\section{Measurement of zeta potential}

It is important to measure the zeta potential and surface charge of emulsified particles on the stability of emulsions. The power of electrostatic impulsion has a significant contribution to prevent flocculation and coalescence (Çelebi, 2009). Change in the net surface charge on the surface of native apricot kernel bodies was $\sim 0 \mathrm{mV}$. The zeta potential of oil bodies is governed by the active component oleosins present on the surface.

The zeta potentials of apricot kernel milk and roasted apricot kernel milk were monitored during $2 \mathrm{~h}$ of gastric digestion and $2 \mathrm{~h}$ of intestinal digestion (Figure 4). The 


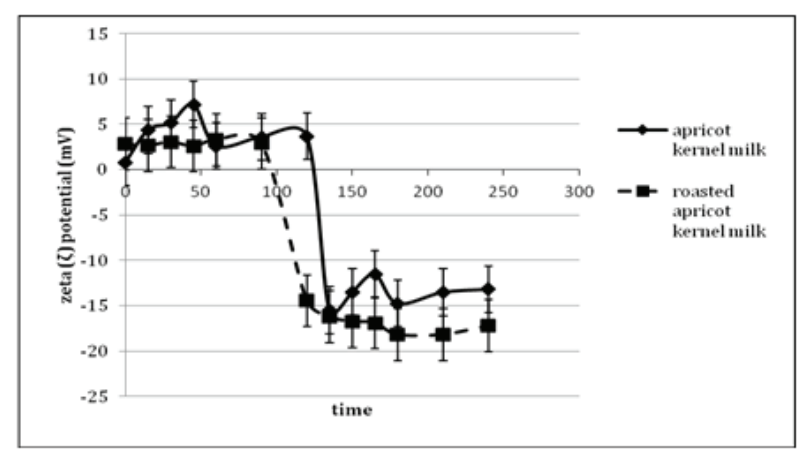

Figure 4. The zeta-potentials of in vitro gastric and intestinal digested samples.

zeta potential of apricot kernel milk was $\sim 0 \mathrm{mV}$ at the beginning of in vitro gastric digestion; moreover, it was increased to $+7.17 \mathrm{mV}$ in the 45th min of gastric digestion. At the end of gastric digestion, the zeta potential of apricot kernel milk was $+3.68 \mathrm{mV}$. The positive value of zeta potential indicated that electrostatic repulsion in protein-stabilized oil droplets decreased and caused flocculation because of the low $\mathrm{pH}$ value of gastric environment. During in vitro gastric digestion, the zeta potential of roasted apricot kernel milk was different from that of apricot kernel milk. The zeta potential of roasted sample did not change during 0-90 min of in vitro gastric digestion and was approximately $+3.0 \mathrm{mV}$ (Figure 6). Moreover, zeta potential was $-14.47 \mathrm{mV}$ in $120 \mathrm{~min}$ of in vitro gastric digestion. Low zeta potential $(0- \pm 5)$ indicated that the solution or dispersion might have rapidly coagulated or flocculated. Therefore, the flocculation continued during $90 \mathrm{~min}$ of gastric digestion of roasted apricot kernel milk, but solubilization occurred after this point. However, the low positively charged zeta potential of apricot kernel milk did not change during $120 \mathrm{~min}$ of gastric digestion. Similarly, Makkhun et al. (2015) reported that the emulsion droplets located on the oil bodies of sunflower remained positively charged for $2 \mathrm{~h}$ of in vitro gastric digestion. The zeta potential of apricot kernel milk became negative at the very beginning (0-15 $\mathrm{min}$ ) of intestinal digestion. Moreover, the zeta potential of apricot kernel milk was $-14.45 \mathrm{mV}$ during the $15 \mathrm{~min}$ of intestinal digestion and increased slowly and reached $-13.2 \mathrm{mV}$ at the end of intestinal digestion. During intestinal digestion, the zeta potential of roasted apricot kernel milk remained practically the same ranging from -16.23 to $-18.2 \mathrm{mV}$. Although there was an insignificant difference between the zeta potentials of apricot kernel milk and roasted apricot kernel milk, a slightly higher zeta potential of roasted samples could be related to the more extensive association of bile salts with the surface of oil bodies in roasted apricot kernel milk than that in apricot kernel milk, as reported by Makkhun et al. (2015) for emulsion droplets located on the oil bodies of sunflower.
Although no research has been conducted on the zeta potential of apricot kernel milk, few studies are determined on the oil bodies of almond, pumpkin seed, soybean, and coconut milk. Gallier and Singh (2012) reported that the charge of native almond oil body was highly negative $(-30 \mathrm{mV})$. At the start of in vitro gastric digestion, the zeta potential of almond oil body was highly positive and continued to remain positive during $60 \mathrm{~min}$ of gastric digestion. Along with the in vitro intestinal digestion of almond milk, the zeta potentials of samples were negatively charged. Dave et al. (2019) reported that the zeta potential of oil bodies of coconut milk measured at $\mathrm{pH} 6.1$ was $-13 \pm 1 \mathrm{mV}$. At $\mathrm{pH} 7.5$, the zeta potential of oil bodies in washed cream and that of purified oil bodies were -32.6 and $-33.8 \mathrm{mV}$, respectively. The zeta potentials of oil bodies of pumpkin seeds were different at different $\mathrm{pH}$ values and salt concentrations. An increase in the concentration of salt up to $10 \mathrm{mM}$ at $\mathrm{pH} 3$ increased the positive charge of zeta potential, which decreased with change in the concentration of salt. However, at $\mathrm{pH}$ 7.4, increase in salt concentration from 10 to 100 $\mathrm{mM}$ induced negative potentials. Ishii et al. (2017) studied the interfacial and emulsifying properties of two types of oil bodies extracted from soybean seeds at different $\mathrm{pH}$ values. The zeta potentials of purified oil bodies (OB) and crude oil bodies (OBC), including storage and other minor proteins, were -14.2 and $-39.0 \mathrm{mV}$, respectively. This indicated that there was a strong electrostatic repulsion between crude oil bodies than between purified oil bodies.

\section{Optical microscopy}

Spherical and variable size of oil bodies were observed for apricot kernel milk and roasted apricot kernel milk (Figures 5A and B). The size of oil bodies of apricot kernel milk was greater than that of roasted apricot kernel milk. Unlike oil bodies of apricot kernel milk, roasting caused aggregation of oil bodies (Figure 5B, $0 \mathrm{~min}$ ). Zaaboul et al. (2019) reported that roasted peanut oil bodies were larger compared to raw peanut oil bodies. The flocculation started within the $15 \mathrm{~min}$ of gastric digestion of both samples (Figures 5A and B). Large aggregates were still present after $90 \mathrm{~min}$ of gastric digestion of apricot kernel milk, but disruption in aggregates commenced in roasted apricot kernel milk at $90 \mathrm{~min}$ of gastric digestion. This result is supported by the increased zeta potential of roasted apricot kernel milk after 90 min of gastric digestion. The flocculation probably occurred due to the destabilization of oil bodies during hydrolysis of interfacial proteins by pepsin. A similar result indicated that the oil bodies of almond flocculated under low $\mathrm{pH}$ conditions ( $\mathrm{pH}$ 1.5) during gastric digestion (Gallier and Singh, 2012). Moreover, a liquid crystalline phase observed 
(A)
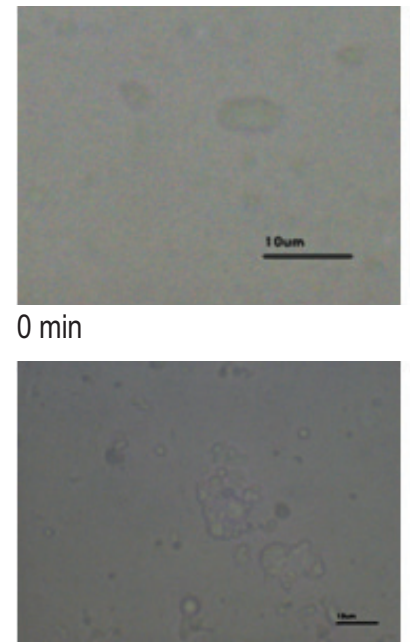

$30 \mathrm{~min}$

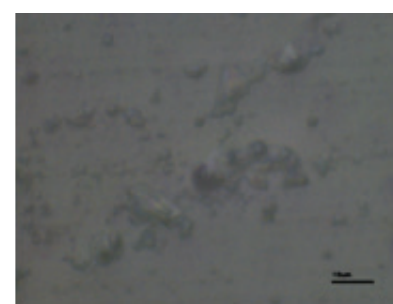

$90 \min$

(B)

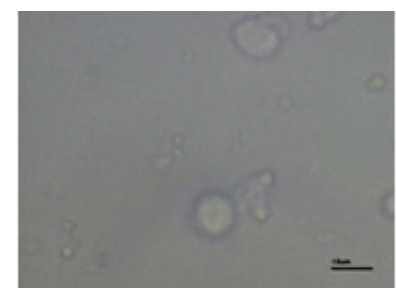

\section{$0 \min$}

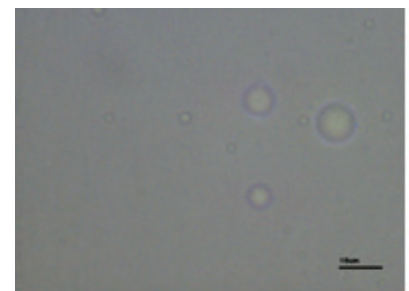

$60 \min$

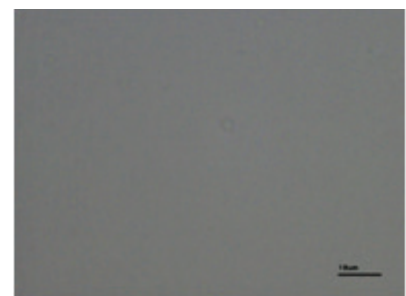

$120 \mathrm{~min}$

Figure 5. (A) Optical microscopic images of apricot kernel milk and (B) roasted apricot kernel milk digests obtained at different time intervals of in vitro gastric digestion.

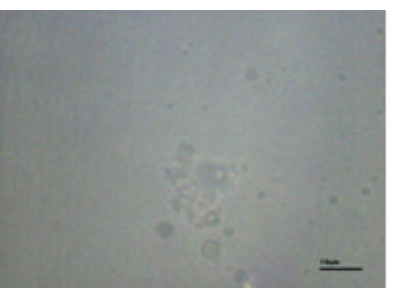

$30 \mathrm{~min}$

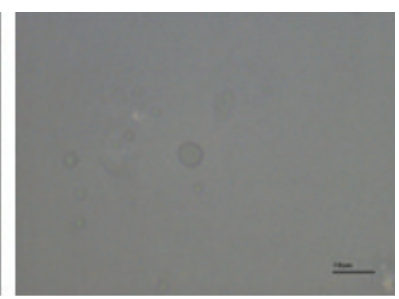

$90 \mathrm{~min}$ surrounding lipid droplets at $90 \mathrm{~min}$ of in vitro gastric digestion (Figure 5B) could be attributed to the presence of insoluble calcium long-chain fatty acid soaps precipitated around oil bodies as reported by Gallier and Singh (2012) in the case of almond oil bodies at 30 min of intestinal digestion.

In the 30th min of intestinal digestion, although large aggregates were still present, marginally disaggregated oil bodies were observed. This disaggregation was probably due to adding bile salts, and pancreatic lipase that they caused to the solubilization of lipolytic products into the mixed micelles formed of bile salts. This solubilization-induced disaggregation of oil bodies after 60 min of intestinal digestion is shown in Figure 6. Gallier and Singh (2012) reported similar behavior of almond oil bodies, revealing the disruption of aggregates after 30 min of intestinal digestion.

Few oil bodies of different sizes were still present at the end of intestinal digestion of apricot kernel milk. However, disaggregation did not occur during $120 \mathrm{~min}$ of intestinal digestion of roasted apricot kernel milk (Figure 6B).

(A)

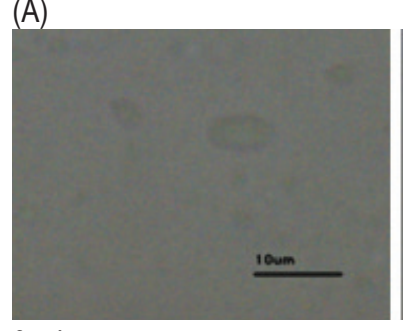

$0 \min$

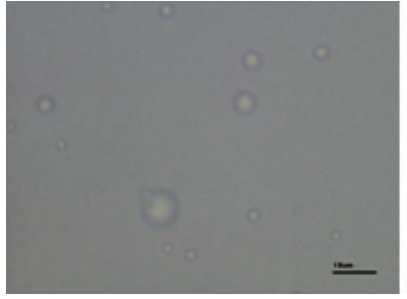

$60 \mathrm{~min}$

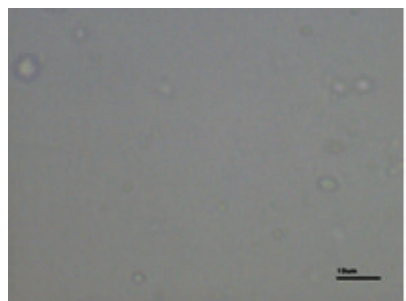

$120 \mathrm{~min}$

Figure 6. (A) Optical microscopic images of apricot kernel milk and (B) roasted apricot kernel milk digests obtained at different time intervals of in vitro intestinal digestion. 
(B)

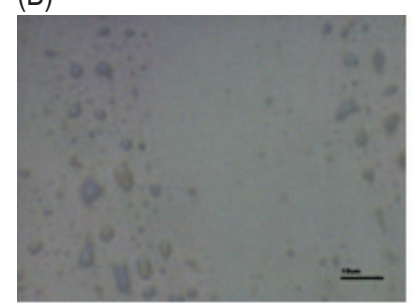

$0 \min$

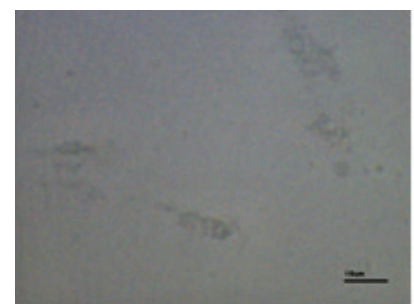

$60 \mathrm{~min}$

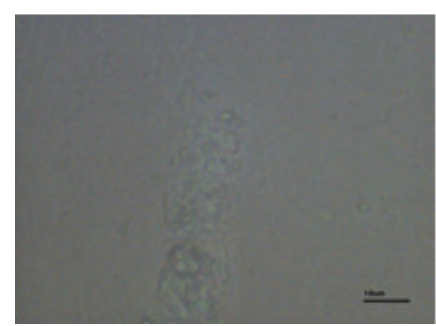

$120 \mathrm{~min}$

Figure 6. (Continued).

\section{Conclusion}

Roasting seems to cause aggregation of oil bodies compared to unroasted apricot kernel milk oil bodies. The proteins of apricot kernel milk and roasted apricot kernel milk were hydrolyzed to a greater or lesser extent during in vitro gastrointestinal digestion. However, pepsinresistant proteins were determined in both samples and the flocculation of oil bodies was observed. No difference was recorded between the pancreatic lipase penetration in the oil-water interface of oil bodies of both milk types. Moreover, a few oil bodies of different sizes were still present at the end of intestinal digestion of apricot kernel milk. However, disaggregation did not occur during $120 \mathrm{~min}$ of intestinal digestion of roasted apricot kernel milk. In addition, $250 \mathrm{~mL}$ of apricot kernel milk contains 50 -g kernel corresponding to $12.5-\mathrm{mg}$ amygdalin, which is considerably lower than the amount $(200 \mathrm{mg})$ that causes poisoning in a child weighing $20 \mathrm{~kg}$, as reported by Karsavuran et al. (2015).

In conclusion, the results of the study demonstrated that apricot kernel milk and roasted apricot kernel milk are a good source of alternative vegetable protein. It could be utilized as a value-added product such as a functional food ingredient and/or a novel functional product. The future research must be conducted on the sensory properties of apricot kernel milk.

\section{Acknowledgments}

We are grateful to Ege University Corporate Development Planning and Monitoring Coordination Unit and Directorate of Library and Documentation for their support in editing and proofreading of this study.

\section{Disclosure Statement}

The authors declare no conflicts of interest.

\section{Funding}

This work was supported by the Ege University Scientific Research Project Coordination (Grant Nos. 8295, 13-MUH-015).

\section{References}

Abdullah, W. and Zhang H. 2020. Recent advances in the composition, extraction and food applications of plant-derived oleosomes. Trends Food Sci Technol. 106:322-332. https://doi. org/10.1016/j.tifs.2020.10.029

Al Juhaimi F., Özcan M.M., Ghafoor K., and Babiker E.E. 2018. The effect of microwave roasting on bioactive compounds, antioxidant activity and fatty acid composition of apricot kernel and oils. Food Chem. 243:414-419. https://doi.org/10.1016/j. foodchem.2017.09.100

Alpaslan M. and Hayta M. 2006. Apricot kernel: physical and chemical properties. J Am Oil Chem Soc. 83(5):469-471. https://doi. org/10.1007/s11746-006-1228-5

Barre A., Simplicien M., Cassan G., Benoist H., and Rougé P. 2018. Oil bodies (oleosomes): occurrence, structure, allergenicity. Rev Fr Allergol. 58:574-580. https://doi.org/10.1016/j. reval.2018.10.005

Beisson F., Ferté N., Voultoury R., and Arondel V. 2001. Large scale purification of an almond oleosin using an organic solvent procedure. Plant Physiol Biochem. 39(7-8):623-630. https://doi. org/10.1016/S0981-9428(01)01275-X

Bligh E.G. and Dyer W.J. 1959. A rapid method of total lipid extraction and purification. Can J Biochem Physiol. 37(8): 911917. https://doi.org/10.1139/059-099

Bradford M.M. 1976. A rapid and sensitive method for the quantitation of microgram quantities of protein utilizing the principle of protein-dye binding. Anal Biochem. 72(1-2):248-254. https:// doi.org/10.1016/0003-2697(76)90527-3

Brodkorb A., Egger L., Alminger M., Alvito P., Assunção R., Ballance S., Bohn T., Bourlieu-Lacanal C., Boutrou R., Carrière F., Clemente A., Corredig M., Dupont D., Dufour C., Edwards C., 
Golding M., Karakaya S., Kirkhus B., Le Feunteun S., Lesmes U., Macierzanka A., Mackie A.R., Martins C., Marze S., McClements D.J., Ménard O., Minekus M., Portmann R., Santos C.N., Souchon I., Singh R.P., Vegarud G.E., Wickham M.S.J., Weitschies W., and Recio I. 2019. INFOGEST static in vitro simulation of gastrointestinal food digestion. Nat Protoc. 14(4):991-1014. https://doi.org/10.1038/s41596-018-0119-1

Çelebi N. 2009. Emülsiyonlar. In "Modern Farmasötik Teknoloji," F. Acartürk, İ. Ağabeyoğlu, N. Çelebi, T. Değim, Z. Değim, T. Doğanay, S. Takka, and F. Tirnaksız (Eds.), p. 277. Türk Eczacılar Birliği Eczacılık Akademisi Yayını, Ankara, Turkey.

Coman V., Teleky B.E., Mitrea L., Martău G.A., Szabo K., Calinoiu L.F., and Vodnar D.C. 2019. Bioactive potential of fruit and vegetable wastes. Adv Food Nutr Res. 91:157-225. https://doi. org/10.1016/bs.afnr.2019.07.001

Dave A.C., Ye A., and Singh H. 2019. Structural and interfacial characteristics of oil bodies in coconuts (Cocos nucifera L.). Food Chem. 276:129-139. https://doi.org/10.1016/j. foodchem.2018.09.125

Elkot W.F., El-Nawasany L.I., and Sakr H.S. 2017. Composition and quality of stirred yoghurt supplemented with apricot kernels powder. J. Agroaliment Process Technol. 23(3):125-130.

Eyidemir E. and Hayta M. 2009. The effect of apricot kernel flour incorporation on the physicochemical andsensory properties of noodle. Afr J Biotechnol. 8:85-90.

Fasolin L.H., Pereira R.N., Pinheiro A.C., Martins J.J., Andrade C.C.P., Ramos O.L., and Vicente A.A. 2019. Emergent food proteinstowards sustainability, health, and innovation. Food Res Int. 125:108586. https://doi.org/10.1016/j.foodres.2019.108586

Femenia A., Rosselló C., Mulet A., and Cañellas J. 1995. Chemical composition of bitter and sweet apricot kernels. J Agric Food Chem. 43:356-361. https://doi.org/10.1021/jf00050a018

Folch J., Lees M., and Sloane Stanley G.H. 1957. A simple method for the isolation and purification of total lipids from animal tissues. J Biol Chem. 226(1):497-509. https://doi.org/10.1016/ S0021-9258(18)64849-5

Food and Agriculture Organization of the United Nations (FAO). 2011. Feeding the future. World Livestock, Livestock in Food Security. Available at: http://www.fao.org/3/i2373e/i2373e03.pdf

Fratianni F., Ombra M.N., d'Acierno A., Cipriano L., and Nazzaro F. 2018. Apricots: biochemistry and functional properties. Curr Opin Food Sci. 19:23-29. https://doi.org/10.1016/j.cofs. 2017.12.006

Gallier S., Acton D., Garg M., and Singh H. 2017. Natural and processed milk and oil body emulsions: bioavailability, bioaccessibility and functionality. Food Struct. 13:13-23. https://doi. org/10.1016/j.foostr.2016.07.005

Gallier S., Gordon K.C., and Singh H. 2012. Chemical and structural characterisation of almond oil bodies and bovine milk fat globules. Food Chem. 132:1996-2006. https://doi.org/10.1016/j. foodchem.2011.12.038

Gallier S. and Singh H. 2012. Behavior of almond oil bodies during in vitro gastric and intestinal digestion. Food Funct. 3:547-555. https://doi.org/10.1039/c2fo10259e

Gallier S., Zhu X.Q., Rutherfurd S.M., Ye A., Moughan P.J., and Singh H. 2013. In vivo digestion of bovine milk fat globules: effect of processing and interfacial structural changes. II. Upper digestive tract digestion. Food Chem. 141:3215-3223. https:// doi.org/10.1016/j.foodchem.2013.06.019

Gezer I., Haciseferogullari H., Özcan M.M., Arslan D., Asma B.M., and Ünver A. 2011. Physico-chemical properties of apricot (Prunus armeniaca L.) kernels. South West J Hortic Biol Environ. 2(1):1-13.

Ghorab H., Lammi C., Arnoldi A., Kabouche Z., and Aiello G. 2018. Proteomic analysis of sweet algerian apricot kernels (Prunus armeniaca L.) by combinatorial peptide ligand libraries and LCMS/MS. Food Chem. 239:935-945. https://doi.org/10.1016/j. foodchem.2017.07.054

Ishii T., Matsumiya K., Nambu Y., Samoto M., Yanagisawa M., and Matsumura Y. 2017. Interfacial and emulsifying properties of crude and purified soybean oil bodies. Food Struct. 12:64-72. https://doi.org/10.1016/j.foostr.2016.12.005

Karsavuran N., Charehsaz M., Celik H., Asma B.M., Yakıncı C., and Aydın A. 2015. Amygdalin in bitter sweet seeds of apricots. Toxicol Environ Chem. 96(10):1564-1570. https://doi.org/10.10 80/02772248.2015.1030667

Makkhun S., Khosla A., Foster T., McClements D.J., Grundy M.M.L., and Gray D.A. 2015. Impact of extraneous proteins on the gastrointestinal fate of sunflower seed (Helianthus annuиs) oil bodies: a simulated gastrointestinal tract study. Food Funct. 6:125-134. https://doi.org/10.1039/ C4FO00422A

Mandalari G., Faulks R.M., Rich G.T., Lo Turco V., Picout D.R., Lo Curto R.B., Bisignano G., Dugo P., Dugo G., Waldron K.W., Ellis P.R., and Wickham M.S.J. 2008. Release of protein, lipid, and vitamin $\mathrm{E}$ from almond seeds during digestion. J Agric Food Chem. 56:3409-3416. https://doi.org/10.1021/ jf073393v

Mantzouridou F.T., Naziri E., Kyriakidou A., Paraskevopoulou A., Tsimidou M.Z., and Kiosseoglou V. 2019. Oil bodies from dry maize germ as an effective replacer of cow milk fat globules in yogurt-like product formulation. LWT-Food Sci Technol. 105:48-56. https://doi.org/10.1016/j.lwt.2019.01.068

Mat D.J.L., Le Feunteun S., Michon C., and Souchon I. 2016. In vitro digestion of foods using $\mathrm{pH}$-stat and the INFOGEST protocol: impact of matrix structure on digestion kinetics of macronutrients, proteins and lipids. Food Res Int. 88:226-233. https://doi. org/10.1016/j.foodres.2015.12.002

Mattheus B., Özcan M.M., and Al Juhaimi F. 2016. Fatty acid composition and tocopherol content of kernel oil from apricot varieties (Hasanbey, Hachaliloglu, Kabaasi, and Soganci) collected at different harvest times. Eur Food Res Technol. 242:221-226. https://doi.org/10.1007/s00217-015-2533-8

Minekus M., Alminger M., Alvito P., Ballance S., Bohn T., Bourlieu C., Carrière F., Boutrou R., Corredig M., Dupont D., Dufour C., Egger L., Golding M., Karakaya S., Kirkhus B., Le Feunteun S., Lesmes U., Maclerzanka A., MacKie A., Marze S., McClements D.J., Ménard O., Recio I., Santos C.N., Singh R.P., Vegarud G.E., Wickham M.S.J., Weitschies W., and Brodkorb A. 2014. A standardised static in vitro digestion method suitable for food-an international consensus. Food Funct. 5:1113-1124. https://doi. org/10.1039/C3FO60702J 
Mirzaei H. and Rezaei K. 2019. Amygdalin contents of oil and meal from wild almond: effect of different heat pretreatment and extraction methods. J Am Oil Chem Soc. 96:1163-1171. https:// doi.org/10.1002/aocs.12257

Morais D.R., Rotta E.M., Sargi S.C., Schmidt E.M., Guntendorfer Bonafe E., Eberlin M.N., Sawaya A.C.H.F., and Visentainer J.V. 2015. Antioxidant activity, phenolics and UPLC-ESI[-]-MS of extracts from different tropical fruits parts and processed peels. Food Res Int. 77(3):392-399. https://doi.org/10.1016/j. foodres.2015.08.036

Sığırcı M., Hasdemir M., Akçay M., and Yurtkulu V. 2015. National Apricot Workshop, p. 80. Turkey Ministry of Agricultural and Forestry, Ankara, Turkey.

Tarım U., Piyasaları-Kayısı. 2020. Turkey Ministry of Agricultural and Forestry, Agricultural Economic and Policy Development Institute. https://arastirma.tarimorman.gov.tr/ tepge/ Belgeler/PDF\%20Tar\%C4\%B1 m\%20\%C3\%9Cr\%C3BCnleri \%20Piyasalar\%C4\%B1/2020-Ocak\%20Tar\%C4\%B1m\%20\%C3\% 9Cr\%C3\%BCnleri\%20Raporu/Kay\%C4\%B1s\%C4\%B1\%20Tar\% C4\%B1 m\%20\%C3\%9Cr\%C3\%BCnleri\%20Piyasa\%20Rapo ru\%202020\%20ocak.pdf. Accessed 1 March 2020.

Wang X., Ye A., and Singh H. 2020. Structural and physicochemical changes in almond milk during in vitro gastric digestion: impact on the delivery of protein and lipids. Food Funct. 11:4314-4326. https://doi.org/10.1039/C9FO02465D

White D.A., Fisk I.D., Mitchell J.R., Wolf B., Hill S.E., and Gray D.A. 2008. Sunflower seed oil body emulsions: rheology and stability assessment of a natural emulsion. Food Hydrocoll. 22(7):12241232. https://doi.org/10.1016/j.foodhyd.2007.07.004.

Wu H., Shi J., Xue S., Kakuda Y., Wang D., Jiang Y., Ye X., Li Y., and Subramanian J. 2011. Essential oil extracted from peach (Prunus persica) kernel and its physicochemical and antioxidant properties. LWT-Food Sci Technol. 44:2032-2039. https://doi. org/10.1016/j.lwt.2011.05.012

Yan Z., Zhao L., Kong X., Hua Y., and Chen Y. 2016. Behaviors of particle size and bound proteins of oil bodies in soymilk processing. Food Chem. 194:881-890. https://doi.org/10.1016/j. foodchem.2015.08.100

Zaaboul F., Raza H., Cao C., and Yuanfa L. 2019. The impact of roasting, high pressure homogenization and sterilization on peanut milk and its oil bodies. Food Chem. 280:270-277. https://doi.org/10.1016/j.foodchem.2018.12.047

Zderic A., Almeida-Rivera C., Bongers P., and Zondervan E. 2016. Product-driven process synthesis for the extraction of oil bodies from soybeans. J Food Eng. 185:26-34. https://doi.org/10.1016/j. jfoodeng.2016.03.030 